\title{
O Desempenho Atoral Rapsódico
}

Nara Keiserman*

Esta escrita especifica a atuação rapsódica praticada pelo Núcleo Carioca de Teatro, dirigido por Luiz Arthur Nunes, do qual sou co-fundadora e onde estive como atriz e preparadora corporal de 1991 a 2002. Durante este período foram encenados: $A$ Vida Como Ela É, contos de Nelson Rodrigues (1991 e 2002), Cândido ou O Otimismo, novela de Voltaire (1993), Tragédias Cariocas Para Rir, contos de vários autores (1996), Correio Sentimental de Nelson Rodrigues, as cartas escritas com o pseudônimo de Myrna (1999), A Prosa do Nelson, contos, crônicas e reportagens de Nelson Rodrigues (2000) e Um Menino de Paixões de Ópera, crônicas autobiográficas de Nelson Rodrigues (2000) ${ }^{1}$.

A denominação de "rapsodo" para este ator foi adotada por Nunes para reforçar a identificação com o modo épico de exposição de relatos, remetendo aos rapsodos gregos que recitavam trechos da llíada e da Odisséia.

O propósito artístico do grupo - reunido após a montagem de $A$ Maldição do Vale Negro, de Luiz Arthur Nunes e Caio Fernando Abreu, em 1988 - foi claro desde o início: investir numa linguagem que explorasse a teatralidade, envolvendo todos os aspectos da encenação, a partir da premissa de se montar textos da literatura ficcional, em que a voz narradora é mantida no palco.

Instalada no palco a voz do autor, convertido em personagem narradora, as formas épica e dramática passam a conviver num jogo produtivo de intercâmbios. A explicitação deste jogo é parte da linguagem, que se propõe revelar seus próprios procedimentos. Assim como o autor não desaparece nos personagens, o diretor não esconde o uso dos recursos e estratégias de encenação. Está assumida a linguagem do teatralismo épico. Os recursos

*Nara Keiserman, atriz, diretora, pesquisadora e professora na Escola de Teatro da UNIRIO. Mestre pela USP, com a Dissertação A Preparação Corporal do Ator: Uma Proposta Didática e Doutora pela UNIRIO, com a tese Caminho Pedagógico Para a Formação do Ator Rapsodo. 
mobilizados pelo diretor estão numa estatura de signos, vocabulário e gramática, que apresentam ostensivamente a sua condição de código.

$\mathrm{O}$ ator de que se ocupa esse texto, e objeto de minha investigação em pesquisas que desenvolvo também fora do $\mathrm{Núcleo}^{2}$, é aquele que trabalha a composição de seu desempenho num teatro em que a própria dramaturgia está, em maior ou menor grau, na categoria do épico. Esta espécie de atuação, que pode ser chamada de expositiva, demonstrativa ou distanciada, é determinada pela atitude narrativa do ator e pelas funções que exerce, de encaminhar as ações, de comentá-las, de introduzir personagens, e em que se evidenciam o jogo entre as duas instâncias pelas quais estabelece sua comunicação com os outros atores em cena e com o público, a verbal e a gestual.

Coexistem nas montagens do Núcleo Carioca de Teatro duas categorias principais de entidade narradora, a que denominamos de narradorpersonagem e de personagem-narrador, que determinam, para o ator a composição de diferentes corpos:

O narrador-personagem é onisciente e se manifesta na terceira pessoa, com maior ou menor grau de opinião e adesão afetiva ao relato. Mesmo não sendo uma figura actante deste, está num patamar ficcional, de personagem cuja função é narrar, e não se confunde com a figura pessoal do autor. É o dono da voz autoral que conduz a narrativa, mas não pretende corporizá-la, no sentido de assumir o seu papel, de "ser" Nelson Rodrigues, por exemplo, ao narrar os contos de $A$ Vida Como Ela É. Em relação à espacialização da cena, poderá estar colocado num lugar afastado, como utilizado em Selvageria e Doente, de A vida Como Ela É, ou compartilhar o espaço da cena com os personagens ficcionais, estabelecendo com eles, inclusive, uma interação fisicalizada em toques e/ou olhares. Neste caso, a participação afetiva pode ser acentuada, como experimentamos em Despeito, de A Vida Como Ela É e Noite de Almirante, de Machado de Assis, em Tragédias Cariocas Para Rir, em que os narradores nutrem, pelos protagonistas, uma simpatia evidenciada no modo enunciativo, nos gestos e nas locomoções.

O personagem-narrador se manifesta na primeira pessoa, e sua visão do relato será sempre parcial, já que participou dos eventos ficcionais como protagonista (O Morto, de Orígenes Lessa e Obscenidades de Uma Dona de Casa, de Ignácio de Loyola Brandão, em Tragédias Cariocas Para Rir), ou como coadjuvante (o personagem do Médico em Noiva da Morte, de A Vida Como Ela É).

Há ainda situações em que a narrativa introduz personagens que se ex- 
põem através de diálogos ou, como ocorre muitas vezes em Cândido, este personagem fruto do relato é também incumbido de narrar.

O ator rapsodo vai transitar entre estes corpos, passando de um para o outro com fluência e ostentação, podendo mesmo chegar a habitá-los simultaneamente, no caso em que empresta a voz à narração pretérita, enquanto seu corpo fisicaliza o personagem, presentificando- $0^{3}$.

Inserido numa tendência do teatro contemporâneo, o trabalho do ator rapsodo ecoa, evidentemente, certos princípios brechtianos, como a não-metamorfose do ator no personagem, base da abordagem atoral brechtiana. Termos como "acreditar" e "defender" o personagem, tão comuns num outro teatro, neste trabalho simplesmente não são levados em conta, ou sequer mencionados. O fato de não estar colado ao personagem e sim distanciado dele, oferece ao ator um espaço a ser preenchido por uma opinião, um ponto de vista - fundamental tanto no teatro brechtiano quanto no rapsódico. Mesmo no caso do personagem narrador ser o protagonista da história narrada, ele estará sempre colocado, por diferentes recursos da linguagem da encenação disponíveis, em algum grau de distanciamento que permita revelar este seu caráter de manipulador e de encaminhador do relato.

O ator é incumbido de corporizar (dar corpo e voz), fisicalizar (em atitudes, gestos, posturas, ações), de representar (em linguagem teatral) a interface entre o épico e o dramático. Neste ato, em que se apodera da voz autoral, tanto no sentido do autor do texto quanto no do autor do espetáculo, e na mesma medida que estes, o ator tem seu temperamento, talento e aptidões revelado - pelo simples fato da não metamorfose completa no papel que representa. As palavras usadas para designar a relação do ator com os personagens são: fazer o papel de, representar, falar em nome de, figurar, ilustrar, compor. As três primeiras expressões remetem a uma situação em que alguém (o ator) se coloca no lugar de outro (o personagem) para, numa cerimônia qualquer (o acontecimento teatral), falar em seu nome (fazer o seu papel). Os outros dois verbos, figurar e ilustrar, estão associados a desenho corporal no espaço, enfatizando a visualidade da realização. Quando se diz que o ator compõe, está se afirmando a disponibilização, pelo ator, de um nível de consciência perceptiva, da orquestração do aparato expressivo, da organização seqüencial dos esforços imprimidos, passíveis de algum tipo de registro em descrição textual.

O verbo ser está ausente deste processo atoral. Estamos na categoria do distanciamento, do teatro "apresentacional", em que tudo é mostrado e não vivenciado. 
Nada disso, entretanto, elimina a sinceridade da atuação. Mesmo transitando nas categorias do grotesco, da tipificação ou do melodrama, como ocorre em algumas montagens do Núcleo, o ator trabalha lidando com a verdade da cena. Os traços que vão marcar suas composições estão fundados em aspectos reconhecíveis do caráter do personagem, e distinguíveis no texto. O ator rapsodo não necessita de uma psicologia que justifique suas ações, já que a aproximação entre o ator e o personagem não se dá pela via da identificação, mas por um acesso determinado pelo exercício constante e claro de um ponto de vista. É este que vai atuar para o estabelecimento da lógica, dos objetivos, da linha contínua da ação - para usar a terminologia de Stanislavski. O ponto de vista será sempre o do narrador, falando em seu próprio nome, ou filtrado pelo personagem em nome de quem fala neste ou naquele momento.

Neste contexto, a gestualidade ilustrativa é procedimento fundamental para o estabelecimento da cena rapsódica. Temos utilizado a expressão "linguagem gestual" do ator no sentido de uma composição formal conectada a um sentido manifesto e passível de leitura sígnica, que poderá acompanhar, complementar ou substituir o enunciado verbal, forjando a própria linguagem estética para a cena. A linguagem gestual do ator rapsodo será sempre passível de uma classificação tipológica. Seu caráter formal suporta um tipo de decupagem, que tem como referências físicas principais as partes do corpo envolvidas no movimento e os Fatores do Esforço do Movimento mencionados por Laban: peso, tempo, espaço e fluência. São estes os parâmetros físicos de que dispus para elaborar as partituras gestuais do meu desempenho nas montagens do NCT. O gesto ganha uma estatura idêntica ao texto na sua intencionalidade de revelar o trabalho já realizado, como se o ator dissesse para o espectador, durante a apresentação: "meus gestos foram ensaiados, preparados cuidadosamente, exigiram-me esforço e maestria, e agora, eu observo minha execução tanto quanto vocês". As encenações empreendidas têm a qualidade da ostentação dos procedimentos teatrais, da própria representação, do "ensaiado". Abordamos o espectador pela via intelectiva, apostando na configuração de um teatro em que pensar emociona.

\section{Modo de elaboração}

Caracterizam o trabalho do Núcleo Carioca de Teatro aspectos que se referem ao modo processual dos ensaios. Trata-se de um coletivo em que os mesmos atores e diretor estão presentes em todas as montagens, e isso certamente estabelece alguns parâmetros. O entendimento artístico promove uma unidade vertical e horizontal, ou seja, no dia a dia dos ensaios e na 
continuidade entre uma montagem e outra. A personalidade artística de cada ator, presente em todas as montagens, por si só já determina um parentesco entre elas.

Há um treinamento constante. O grupo não inicia cada novo trabalho simplesmente de onde parou o anterior, mas sim retoma todo o cabedal de procedimentos que vem sendo trabalhado, o que garante a continuidade dentro de uma mesma linha mestra de investigação.

A partir de indicações dadas pelo diretor, cabe aos atores especificar e detalhar o seu modo pessoal (e coletivo) de elaboração vocal e gestual, através de experimentação improvisacional, que pode se estender durantes muitos ensaios até que se chegue a resultados considerados definitivos. Feito isso, o diretor passa a exigir, com rigor, a execução do que está estabelecido. Por outro lado, mesmo depois de estabelecida, e com a peça em cartaz, o ator poderá ser solicitado a modificar mais ou menos a sua partiturização de fala e movimento.

Como exemplo do desempenho rapsódico, faço um breve relato do trabalho dos atores, tornando específica a minha própria atuação em duas montagens, A Vida Como Ela É (1991 e 2002) e Correio Sentimental de Nelson Rodrigues, por considerá-las exemplares da pesquisa do Núcleo.

\section{A vida como ela é}

O início do espetáculo, considerando a entrada dos atores e a primeira cena, O Desgraçado, define dois aspectos fundamentais da linguagem: o uso de sombras chinesas e a narratividade que tem o público como destinatário.

Black-out, música de abertura. Os atores entram em cena e sentam, de costas para a platéia. Refletores colocados dentro da caixa do palco, iluminam vagamente a cena, mantendo uma certa penumbra. Vêem-se as figuras silhuetadas de um casal, homem e mulher, projetadas no centro do painel de fundo, em tamanho natural. A posição dos atores em cena sugere que estes, como a platéia, são espectadores do que se vai assistir, são também ouvintes do que se vai contar.

Luz geral para a cena um. Inicia-se O Desgraçado e aquilo que se conta é contado por todos. Com o texto narrativo dividido entre todos os atores, um deles personifica o personagem título do conto. Todos se movimentam numa dinâmica muito ágil, formando e desfazendo grupos de narradores, que por vezes envolvem o protagonista, em outras são ouvintes que comentam entre si - por atitudes, ou pequenas falas - o que está sendo narrado. As cadeiras 
estão espalhadas pela cena, permitindo a realização de diferentes trajetórias, e usadas pelos atores para a composição de quadros com vários planos e alturas diferentes.

A primeira fala apresenta o protagonista, Peixoto. Os outros personagens circunstanciais são exercidos por atores determinados, que saem com naturalidade do plano da narração para passar ao breve plano dialógico. Assim como foi este narrador que assumiu o papel, um outro poderia fazê-lo. Não há qualquer indicação ou preparação para passar de uma função para a outra. Este procedimento de extrema fluência na passagem do placo épico para o dramático vai se tornar uma das marcas mais nítidas e almejadas no trabalho do Núcleo.

Fui uma das narradoras incumbida, como parte deste coral rapsódico, de contar as conseqüências da tara sexual do Peixoto. A elaboração que fiz para cumprir esta função está norteada pela busca de um corpo participativo, envolvido no relato e envolvente em relação a Peixoto. Há pouco espaço para reflexão, no sentido de ação interior. A reflexão que possa fazer sobre o que estou ouvindo é imediatamente exteriorizada, em atitude e jogo de ocupação do espaço.

A segunda cena, Uma Senhora Honesta é feita com o recurso ilustrativo gestual do Quadro Vivo e o texto na técnica da Dublagem. Dois atores fisicalizam os papéis de Luci e seu marido Valverde. Três atores estão sentados em cada uma das laterais, na penumbra, de perfil para a platéia, de frente para a cena que vão comandar com suas vozes. O texto dialógico é feito por dois destes atores, enquanto os outros se encarregam de narrar, comentar, e revelar os pensamentos de Luci e Valverde.

Os protagonistas executam as poses/atitudes adequadas ao texto e se mantêm nelas enquanto não houver um novo impulso de intencionalidade que justifique ou motive uma mudança. É um procedimento de nítido distanciamento, a ilustração sendo totalmente destacada do relato e que as próprias composições gestual e textual tratam de enfatizar. As duas instâncias em que os personagens se manifestam passam por uma construção aproximada do grotesco. As poses são exageradas, contorcidas, mas coerentes com a situação dramática. Os atores trabalham as vozes dos personagens com grandes variações no uso de timbres e extensão vocal.

Coube-me a função textual na figuração de Luci, a senhora honesta. De início, senti uma impossibilidade de escuta interior do texto, eu simplesmente não conseguia ouvi-lo mentalmente, como se este não encontrasse eco dentro de mim, e era como se aquelas palavras não coubessem na minha 
boca. No decorrer dos ensaios, passei a ouvi-las internamente, mas ainda não conseguia reproduzir o que ouvia. Finalmente, com muito empenho e inúmeras repetições fui conseguindo fechar o espaço entre escuta interior e elocução.

Fui para a segunda montagem com o propósito de trabalhar num tom mais grave. Ao ver o vídeo da peça, desagradou-me a voz excessivamente estridente, chegando a comprometer o entendimento do texto. Ao obter o grave como base, o resultado foi que pude usar uma extensão maior, explorar um contraste mais acentuado nos enunciados, pelo uso de intervalos de som consideráveis. Numa mesma palavra de três sílabas, por exemplo, faço uma sétima, do grave para o agudo e voltando, uma nota para cada sílaba - a palavra é "escuta". Devo dizer que não pensei nisto previamente.

Fui emitindo o que ouvia cada vez com mais nitidez e só depois é que pude observar os intervalos e extensão alcançados. A personagem ganhou em determinação e a atriz que se movimentava tornou ainda mais enfática a sua composição corporal de qualidade grotesca.

Outra mudança que adotei para a temporada de 2002 é relativa à postura e atitude corporais. Na primeira montagem, por opção minha e não por indicação do diretor, trabalhei de maneira a manter-me sempre em estado de neutralidade corporal: sentada, com as pernas cruzadas, mãos sobre o joelho, uma sobre a outra. Na segunda montagem, optei por ter os dois pés no chão - uma garantia para o grave e para uma projeção vocal mais firme - e deixei que meu corpo e inclusive o rosto trabalhassem junto com a intencionalidade do texto. O fato de estar numa zona de penumbra da cena era garantia de que estes pequenos movimentos não iriam interferir no espaço da ação.

Selvageria é uma das cenas em que a linguagem está aproximada do realismo, pelo modo como os dois atores protagonistas compuseram seus personagens. Mas é uma chave de realismo que permite o exagero, a exteriorização exacerbada dos sentimentos, uma certa tipificação - principalmente a personagem de Luciana, que exterioriza em pulsão melodramática o seu sofrimento atroz pela morte do amante (notícia falsa dada pelo marido). $O$ momento final, que culmina com sua morte a pontapés, dados pelo marido, é realizado com movimentos sustentados, lentíssimos e extremamente desenhados.

Elemento marcadamente épico é a presença do narrador-personagem que, de fora, sem interferência no espaço da ação, inicia o relato. Em seguida, junta-se aos outros atores para participar do coro de vizinhos, sai de 
cena com eles e volta para finalizar a narração.

Estou no coro dos vizinhos que vêm bisbilhotar o que está acontecendo, atraídos pelos gritos de Luciana. Destaco-me por um momento, para falar em nome da amiga que a aconselha a acalmar-se e volto a me integrar ao coro. Construí a corporeidade desta vizinha sobre uma idéia de espanto pelo que ouve e vê. A boca e olhos bem abertos, ombros elevados, como quem levou um susto e aí ficou. Utilizei essa mesma construção na montagem de 2002.

Em Paixão, o texto está gravado e os personagens da história, Verita e Alcides, são atualizados de duas maneiras. Em cena, utiliza-se um procedimento que mescla os recursos do Quadro Vivo com um tipo de Pantomima estilizada, em que os gestos "mimam" os diálogos e os pensamentos dos personagens.

Os movimentos que levam os atores de uma pose para outra são sempre muito lentos e seu desenho no espaço está impregnado de significações. Esta qualidade confere-lhes a mesma estatura expressiva desempenhada pelas próprias poses.

Nos painéis do fundo, em sombra chinesa com posturas estáticas, estão os mesmos personagens mostrados no palco: Verita e Alcides, a Mãe de Verita e o Médico, figurados ora por atores, ora através de recortes, de maneira alternada ou simultânea. Estabelece-se entre as duas figurações uma relação de duplicação, tornando mais graves os acontecimentos, e mesmo oferecendo deles duas visões. Há um outro fato relevante: os atores em cena são fisicamente muito diferentes dos que estão na sombra. É quase um outro casal de Alcides e Verita, o que expõe a categoria épica da ilustração. Estabelece-se um "é assim, mas também poderia ser assim".

Minha função é a de representar a Mãe de Verita, em sombra, cuja utilização exige que siga certos princípios: buscar a distância adequada entre a tela e o refletor, e na construção da posição, considerar que o corpo deve oferecer espaços para a luz. A parte do corpo que estiver encoberta pelo próprio corpo simplesmente não será projetada. Além disso, não conto com o rosto para figurar a expressão desejada. Todo o jogo expressivo deve ser obtido pela colocação postural e de gestos. Esta cena foi cortada na segunda montagem.

A Cena 5, Romântica, como que engloba os recursos de Paixão e Uma Senhora Honesta. O procedimento textual é o mesmo da dublagem de Uma Senhora Honesta. Os atores narradores e os dubladores dos personagens 
estão sentados, desta vez, ao redor da área de ação e iluminados. Ao invés da ação plasmada em quadros fixos, temos a ação contínua, como se fosse Paixão num tempo mais cotidiano, e não esgarçado como é utilizado ali. Se os personagens fossem os emissores do seu texto, seria tão realista quanto Selvageria.

Faço a voz da Mãe da protagonista - são duas réplicas em dois encontros fugazes com a filha Alicinha, e tenho algumas falas de narração. Minha participação é tão somente textual. Diferentemente do que ocorre em Uma Senhora Honesta, aqui nenhum empenho corporal é exigido para a enunciação adequada de minhas falas.

Noiva para sempre conta a história de duas irmãs, Dorinha e Helena, apaixonadas pelo mesmo homem, Maurício. Os três atores que os representam usam máscaras de látex, cobrindo toda a cabeça e se movimentam conforme a técnica do Fotograma ${ }^{4}$, procedimento bastante utilizado pelo NCT, em que o personagem é manipulado em poses sucessivas por um ator colocado atrás dele que está encarregado também da elocução verbal. Deste modo, as suas falas são dadas pelos manipuladores, que, como os outros personagens do conto, exercem também uma função narrativa. Os atores se dividem, portanto, em: aqueles que compõem personagens que eventualmente narram, atores manipuladores que, como tal, dialogam e também narram e atores que figuram, sem texto, os personagens manipulados.

Minha função é a de manipuladora de Dorinha, a preterida por Edgar, que acaba por matar-se vestida de noiva, no leito nupcial de Helena, sua irmã.

Na manipulação que faço, estabeleço uma variação em relação à direção do olhar: falo por Dorinha olhando para Helena, mesmo que não tenha colocado a atriz que faz o papel com o rosto voltado para ela, olho para Dorinha ou ainda para quem ou para onde ela olha. É interessante olhar na mesma direção do boneco, para firmar uma identidade entre texto e voz, mas é igualmente interessante desvincular as duas categorias de significação. Enfatizar o espaço entre os dois corpos é um meio de ostentar a manipulação ilustrativa do relato.

Como nas outras cenas em que se utiliza o Fotograma e o Quadro Vivo, não é só a postura estática que carrega os significados desejados. Mesmo trabalhando na economia, eliminando qualquer movimento supérfluo na passagem de uma posição para a outra, há um componente do impulso, da tensão com que este movimento é realizado e este sim pode ser significativo. 
No caso de Dorinha, a pose carrega um grau de tensão que é mantido nos movimentos de passagem.

Para Despeito estabeleceu-se um coro de três narradores, configurado como uma narração de dentro, o coro partilhando com os personagens palmo a palmo do espaço em que acontece a história. Onipresente, esse coro comenta e assiste a episódios como os que acontecem dentro da casa de Marlene e seu marido Rafael, as conversas ao telefone entre Marlene e Leocádio, que é o melhor amigo de Rafael e por quem Marlene se descobre apaixonada, e ainda o momento em que Rafael mata Leocádio no seu escritório.

Um momento exemplar da utilização de procedimentos epicizantes é quando o coro narra o que o marido teria dito à Marlene, e o ator que o representa e que está ali ouvindo, completa o texto dizendo simplesmente: "Ouviste bem?"

Meu papel é o da amiga Hermelinda, que dialoga com Marlene estimulando-a, encorajando-a a se entregar para Leocádio. Sinto-me integrada ao coro, com quem interajo através da ocupação harmonizada do espaço e de atitudes de comentários sobre o desenrolar dos acontecimentos, tornandome também narradora em certos momentos. Essa interação com o coro tornou-se mais nítida na segunda montagem.

Construí a corporeidade de Hermelinda sobre a idéia de uma libidinosidade amoral e despudorada. Durante grande parte da cena permaneço sentada e para trabalhar na cadeira estabeleci dois focos principais, que são a boca e as pernas, em movimentos bem nítidos: os braços dobrados, perto do corpo, a mão direita na direção do rosto, a boca entreaberta, a língua encostando-se no dedo anular. Em alguns momentos, passeio o dedo ao redor dos lábios, ou é a cabeça que se movimenta, mantida a mão na mesma posição. Os dedos vão à boca, um por um, mordisco-os e lambo como se estivessem melados - a imagem que me vinha sempre ao pensamento era algodão doce. A estes gestos, contraponho em alguns momentos um foco nas pernas. Com as pernas cruzadas, começo por girar o tornozelo, depois giro o joelho. Mais adiante, estendo as duas pernas cruzadas à frente - estou numa diagonal em relação ao público - o tronco vai para trás, retorno para a posição básica de uma perna cruzada sobre a outra, tronco vem arredondado para frente, fechando a figura. Volto a estender joelhos e tronco, repetindo assim o primeiro movimento, e então descruzo as pernas, levando um pé ao chão. Dobro o outro joelho, erguendo-o de maneira que o pé encoste-se ao joelho da perna que está apoiada no chão. Estendo novamente as pernas cruzadas à frente e refaço o movimento anterior: um pé no 
chão e o outro encostado no joelho. Repito esta seqüência algumas vezes, de maneira sincronizada com a música e com o texto em que Marlene seduz Leocádio ao telefone.

Em Noiva da Morte é o ator que faz o papel do Médico da família quem narra a história de Alipinho, na primeira pessoa. O coro de tias encarrega-se de comentários e de curtas falas de diálogo. A composição carrega com despudor na caricatura destas figuras, praticamente alegorias da repressão e do falso moralismo burguês.

Estou no coro das tias. Parti de uma idéia de extrema contenção para estabelecer o tronco ereto, rigidamente colocado. $O$ movimento rápido da mão que movimenta o leque provocou uma repercussão nos ombros, que se movimentam com a mesma qualidade do movimento das mãos, em fortes sacudidas ritmadas, durante as locomoções. Movimentos pontuados de cabeça, com inclinações firmes do tronco na direção dos focos de atenção, completam a composição.

Em Doente tem-se um narrador de fora com poucas intervenções e os dois protagonistas na técnica que chamamos de Bonecos Chineses - atores manipulados em ação contínua, o manipulador colocado atrás, assoprando de forma visível e às vezes até audível pela platéia o texto que deverá ser dito pelo ator que representa o personagem.

Doente conta a história da mulher que trai o marido compulsivamente e ao final enforca-se com o fio do ferro elétrico. Esta imagem aparece no recorte em sombra. $\mathrm{O}$ ator que faz o marido, Olímpio, está ajoelhado no centro do palco, seus gestos de desespero endereçados à sombra.

Estou no papel de Georgette, a protagonista. Entro em cena sendo manipulada. Minha primeira fala me é assoprada nesta trajetória, de modo que ao chegar na marca eu já possa pronunciá-la. A elaboração da fisicalidade desta composição, com todos os seus desdobramentos, envolve muitas questões físicas para a sua execução, com parâmetros como: tensionamento muscular, caminhos do movimento dentro do corpo, uso do tempo, entendimento dos códigos de movimento da parceira, percepção dos sentidos: audição e visão. Vou me referir a estes aspectos, a fim de oferecer uma visão completa do trabalho.

Há um grau de densidade muscular básico que deve ser exercido pelo manipulado, que é o da tonicidade equilibrada, em que o corpo está ao mesmo tempo leve e auto-sustentado, flexível para que o manipulador possa movimentá-lo sem esforço. A tonicidade do personagem vai sofrer mudan- 
ças, na medida em que ele vivencia estados emocionais diversos. Trata-se, portanto, para o ator, de estar disponível para a manipulação e também para o personagem, emprestando diferentes graus de tensão para diferentes partes do corpo, modificando-os instantaneamente quando necessário.

É da técnica a idéia do movimento repercussivo. O manipulador leva meus braços numa determinada direção, e correspondendo ao impulso dado a este movimento, a ele vão aderir, ou não, cabeça, tronco e pernas. Mas este efeito vai depender da densidade (tensão) corporal exercida no momento, e de qualquer coisa como os caminhos do movimento dentro do corpo, o que é absolutamente pessoal. Passa por determinantes como flexibilidade, anatomia, maior ou menor experiência em trabalho corporal e sincronismo com o parceiro.

Ao interagir com o outro personagem, que está sendo manipulado da mesma forma, minhas percepções e atitudes estão voltadas para ele. Mas tenho que estar ouvindo o que me diz o manipulador, que segue pronunciando baixinho em meu ouvido a fala que já iniciei ou a próxima. Meu olhar não pode ausentar-se do meu foco, que está eventualmente a minha frente, nem meus ouvidos tornarem-se surdos ao que diz o meu manipulador (que está nas minhas costas), o que resultaria num desastrado e indesejável esvaziamento da expressão. Tenho que ampliar a minha escuta e manter vivo o meu olhar, divididos entre focos diferentes.

Quanto ao uso do fator tempo, há a duração do gesto, o tempo de escuta do texto do interlocutor, o tempo entre a escuta da fala assoprada e a sua emissão. Do ponto de vista do manipulado, a opção que se coloca é entre: esperar que o manipulador assopre toda a fala para só então repeti-la ou ir repetindo a medida em que a vai escutando. O certo é que os gestos devem corresponder ao texto. A manipulação corporal deve seguir as intenções do texto, o que não quer dizer que iniciem juntas. Todo o processo de construção da cena é favorecido pelo conhecimento mútuo dos códigos de expressão gestual do manipulador e manipulado. E isto só o treinamento na técnica, os inúmeros ensaios e repetições, acompanhados de um desejo e empenho verdadeiros de acertar é que podem vir em auxílio dos atores.

A todas essas questões acrescentam-se as trazidas pelo próprio conto. Georgette chora muito, desesperada da sua doença, cheia de culpa, remorso e amor pelo marido. Como cuidar de todos estes procedimentos corporais e ainda assim obter uma autenticidade na expressão de sentimentos como esses? Como chorar de forma verossímil enquanto a atriz atrás de mim vai dizendo o que eu devo dizer a seguir, em falas em que confesso minha traição, assumo com desespero a fatalidade de uma separação indesejada? 
Não sei exatamente por que caminhos vivifico meu aparato emocional, mas posso dizer que a expressão do choro incontido vem com o gesto impingido pelo manipulador, vem com o próprio texto, não importando se este é gerado por mim ou por quem está atrás de mim e tem o comando.

Esta cena foi a que nos deu mais trabalho, que mais tempo de ensaios exigiu e preciso confessar que, diferentemente das outras, a execução dessa cena nem sempre me satisfez - e isto nas duas montagens.

O Justo foi concebido com uma particularidade. A trilha sonora foi sendo concebida simultaneamente à cena. Compúnhamos os movimentos sobre a música sugerida. Não podemos supor uma execução desta cena sem essa música que a fundamentou.

Com exceção feita ao protagonista, ao redor do qual o conto é construído, os demais personagens assumem as falas de narração que conduzem os acontecimentos e fazem os comentários que a enriquecem. É uma narração de dentro do espaço da ação, dada no tom adequado ao que cada um estipulou como traço principal para o seu personagem. Apenas dois deles, Isaurinha, a filha de criação e Juca, o filho mais moço, têm falas narrativas na primeira pessoa.

Esta é a cena, comparável com Despeito, em que a narração é totalmente inserida na ação. Todos ouvem e reagem ao que o personagem narrador está dizendo para a platéia. Neste procedimento, os textos narrativos endereçados para dentro da cena acabam por se constituir em verdadeiros diálogos.

O jogo épico, num cenário totalmente em aberto como o nosso, permite a troca de ambiente numa simples mudança de direção do corpo do ator, por exemplo, ou a fala narrativa resolve estas passagens, não só de espaço como de tempo. Exemplo: o Pai chama Juca para conversar no escritório. Os dois atores estão sobre o praticável que já foi utilizado como sendo tanto a mesa de jantar da sala da família, quanto o quarto de Isaurinha e um corredor da casa. O Pai pede a Juca que o acompanhe até o escritório, e basta que um cruze pelo outro e está desenhado o escritório. Ali, o Pai se mata, sendo o ato indicado por um simples gesto do ator de apontar um revólver na direção da cabeça, no acorde forte da música. Numa atitude antiilusionista de ostentação do teatral, o ator deita-se no praticável, coloca a arma ao lado do corpo e cruza as mãos sobre o peito. Os outros personagens vão se aproximando, contritos. Está configurado o velório.

Faço o papel da Mãe. O figurino - um vestido fechado de lã, na altura 
dos tornozelos, mangas compridas, chapéu alto e reto, empresta uma sobriedade européia (sinto-me uma mulher russa) a esta figura reprimida pela autoridade incontestável do marido. A situação terrível - a filha adotiva aparece grávida e todos os homens da casa são suspeitos da paternidade - trouxe-me os ombros altos, para frente, mãos entrelaçadas na altura do peito, boca apertada com os lábios repuxados para baixo. A posição atrás da mesa obriga a movimentos largos e definidos de tronco. $O$ fato de ter concebido a partitura de falas e gestos do personagem sobre a música, trouxe-me uma clareza nos tempos da respiração utilizados, como se viesse daí o temporitmo da expressão fisicalizada do personagem.

O Aleijado tem a mesma chave interpretativa de Selvageria. A narração é iniciada por um amigo do protagonista, de nome Sandoval. O tom é jocoso, brincalhão, afinal o "drama" é que Sandoval só gosta de mulher casada. Para seduzi-lo, Sônia que é apaixonada por ele desde menina, casa-se com um homem que tem uma perna mais curta que a outra, e por isso não pode pretender que ela the seja fiel. Quando Sandoval se cansa de Sônia e a abandona, o personagem título, Domício, ameaça matá-lo. O texto narrativo, que é extremamente econômico, vai passando por todos os personagens, cada um responsável pelos trechos em que está envolvido no acontecimento de que trata a narração. .

Faço o papel de Sônia e aqui temos uma vantagem do épico. Sou muito mais velha que o personagem (notadamente na segunda montagem, realizada dez anos depois da primeira) e isso não tem a menor importância. Não pretendo me fazer passar por Sônia, mas faço o seu papel, represento-a. Então vou muito à vontade, em movimentos largos e ondulantes, seduzindo Sandoval pelo telefone, com voz grave e provocante. Desfaço essa voz, que é truque do personagem para impressioná-lo, e passo para uma voz mais adequada à sua juventude, mais aguda, esfuziante. Minha chave é a leveza, a presteza em passar de uma situação para outra, na alegre irresponsabilidade dos atos do personagem. Mesmo nas falas de narração mantenho o tom de agrado pelo modo como os acontecimentos vão se desenrolando.

Na figuração das carícias amorosas de Sônia e Sandoval, enquanto o marido dorme depois do jantar, optamos por uma representação em que Sandoval está sentado, de frente para a platéia. Sento com as pernas afastadas e de frente para ele, sobre uma das suas pernas. Ele me sustenta pela cintura, dando-me apoio para o movimento que vou fazer, de girar o tronco de um lado para outro, arqueando-me cada vez mais para trás, rindo muito até retornar num único movimento para a posição inicial, desta vez em relaxamento, braço apoiado no encosto da cadeira em que está o ator. 
A cena termina quando Sandoval, pressionado por Domício, vem jantar novamente na casa do casal. Sentamo-nos os três à mesa, ao redor de uma sopeira e eu anuncio, singelamente, que jantamos.

É o final da peça. Os outros atores juntam-se a nós, formamos um quadro. Ilumina-se todo o painel do fundo, que está inteiramente tomado pelas sombras em recorte utilizadas no decorrer da peça. A música é Juízo Final, de Nelson Cavaquinho e diz que: "(...) do mal será queimada a semente / o amor será eterno novamente".

\section{Correio Sentimental de Nelson Rodrigues}

A peça é composta das cartas do correio sentimental e do folhetim A MuIher que Amou Demais, a que vou me ater porque permite analisar a atuação rapsódica num texto dialógico.

Escrito em vinte e cinco capítulos, com todos os elementos típicos do foIhetim, A Mulher Que Amou Demais foi adaptado para o espetáculo em cinco inserções, intercaladas pelas cartas de Myrna, abrangendo toda a gama de acontecimentos do original.

Temos vários níveis de narração: Myrna (feita por uma única atriz, diferentemente do que ocorre nas cartas, em que se tem sempre o coletivo de narradores) é onisciente e introduz os personagens que ilustram a história de Lúcia, a protagonista. Estes personagens se expressam através de diálogos e, algumas vezes, estão encarregados de falas em que narram o seu passado. Lúcia trafega entre estes os dois mundos, o habitado por Myrna e o dos personagens que presentificam a sua história. É a única a perceber a presença de Myrna junto a ela, fazendo-Ihe confidências e manifestando, em linguagem narrativa, pessoalizada, os seus desejos, angústias, esperanças. Constitui-se, assim, em uma colaboradora na narração da história, chegando mesmo a completar frases iniciadas por Myrna.

A manipulação ostensiva com que Myrna conduz o relato faz com que os atores, na composição dos seus personagens, adotem uma corporeidade que sugere a presença de um manipulador imaginário, o que resulta em gestos extremamente desenhados no espaço e sustentados no tempo. Próximos à impostação melodramática, e sem ferir qualquer princípio de verossimilhança, possuem acentos descotidianizados e complexos.

Houve uma peculiaridade na construção do desempenho atoral no foIhetim. O texto nos foi entregue pelo diretor adaptador em capítulos, como 
um folhetim que se preze, à medida que ia realizando as modificações necessárias para a transposição do texto para o palco. Portanto, lidávamos, para a criação das primeiras cenas, com informações incompletas sobre os personagens e a trama.

Nos papéis de Dona Dorinha, mãe de Lúcia, e de Dona Olívia, mãe de Carlos e de Paulo, noivo de Lúcia, trabalhei a partir da idéia de estabelecer uma diferença corporal entre as duas - que aliás contracenavam em certos momentos - pela colocação nitidamente diferenciada da coluna vertebral.

O uso de um xale sobre os ombros para uma e ao redor do pescoço para a outra, também oferecia uma distinção. Na verdade, no momento em que eu fazia as duas dialogarem, nem tocava no adereço. A diferenciação davase tão somente no corpo e na voz.

Concebi Dona Olívia ereta, quase rígida no seu sofrimento e austera autoridade. Gestos econômicos, realizados nunca acima da linha da cintura, os braços próximos do corpo, andar firme, lento e cadenciado, de quem não perde o autocontrole - característica que o texto aponta também para o seu filho Paulo.

Para Dona Dorinha, então, por contraste e servindo às circunstâncias do texto, arredondei as costas. Deixando que esta postura repercutisse no corpo inteiro, obtive: inclinação acentuada na cervical, a parte de trás da cabeça quase se encostando à nuca, o queixo alto, gestos igualmente elevados sempre na altura do peito, ganhando amplitude para frente e para os lados, ágeis, nervosos. O caminhar era igualmente rápido, de passos curtos e leves. Na cena em que as duas mães dialogam tornou-se muito simples passar de um corpo para outro com a fluência e prontidão necessárias.

Para a composição dos personagens Carlos e Virgínia foram usadas meias máscaras neutras. Carlos é descrito como um homem belíssimo, quase sobrenatural. Virgínia, tida como morta, reaparece sem memória. Se na atitude dos atores ao comporem seus personagens para o Folhetim aparece um manipulador imaginário, nestes dois, construídos com a máscara, a sua presença parece ser ainda maior.

A composição de Virgínia trouxe-me várias questões. Primeiramente, considerando a própria máscara, foi preciso ter movimentos muito definidos comandados pelo pescoço, já que o olhar do personagem é dado pela direção para onde aponta o nariz. Optei por ter a coluna ereta naturalmente e enfatizar os movimentos dos braços, punhos e mãos. Trabalhei espontaneamente com a palma das mãos para cima - o que me dava uma sensação 
inequívoca de solidão, carência e abandono.

O diretor concebeu a primeira cena de Virgínia e Lúcia ao redor da mesa. Pediu que além de girarmos ao redor dela, também girássemos ao redor de nós mesmas. Estes giros fizeram-me sentir a presença forte das pernas, e todo o jogo de peso/equilíbrio que traduzia a inquietação do personagem. Adquiri também uma percepção muito forte do jogo possível entre os movimentos de braços e pernas, de modo a produzir a leveza e fluência desejadas na figuração géstica do personagem. Havia uma ênfase nas transferências de peso, com ou sem locomoção.

Observei que se eu não tivesse um forte controle do movimento das pernas, seria muito difícil a execução da cena em que Paulo tenta matar Virgínia no barco, cujo movimento é sugerido por um balanço sincronizado entre tronco e pernas. Da mesma forma, na cena em que o personagem caminha pelas ruas como uma sonâmbula o foco vai, mais uma vez, para o controle do movimento das pernas.

Mas alguma coisa, a música talvez, trazia um forte chamamento para os meus punhos. Estou em pé, sobre a mesa/praticável, de frente para a platéia. Carlos, atrás de mim, pronuncia um nome, Virgínia, que ainda não reconheço como meu. Mas é grande a minha comoção. Levo as mãos na altura dos ouvidos, os cotovelos apontando para os lados. Em seguida, vou aproximando-os à frente do corpo, até que as palmas das mãos encubram o rosto/ máscara, os cotovelos baixos, ao mesmo tempo em que me ajoelho. Já ajoelhada, giro os cotovelos para fora e vou, então, estendendo os braços lateralmente, com uma tensão tão forte nos punhos, que demoro a desfazer. Tenho que promover um esforço para estender finalmente as mãos, repetindo sempre "Virgínia, Virgínia..."

É a posição das mãos que marca a diferença no personagem, quando ele recupera a memória: suas palmas voltam-se decididamente para baixo, apontando para dentro, para o corpo.

Pude experimentar mais uma vez o prazer de passar com imediatismo de um corpo para outro, quando, logo após o momento em que Dona Olívia vê seu filho Paulo morto, a narração evoca a cena do assassinato. Colocome de costas para a platéia. Entrego meu xale para um dos atores, e recebo dele a máscara de Virgínia, que coloco imediatamente. O movimento de girar sobre mim mesma, voltando à cena, já se dá em seu nome.

No trabalho que fiz com o Núcleo Carioca de Teatro, foi este personagem, o de Virgínia, que me ofereceu maiores oportunidades de composição 
elaborada. Nos contos encenados ou na novela de Voltaire há uma qualidade de síntese, de precipitação dos acontecimentos que favorece, inclusive, o tipo de teatralidade que nos interessa pesquisar, a da essencialidade.

É uma escrita acelerada, em que o autor não se detém no desenho minucioso dos personagens. Já o Folhetim permitiu uma composição mais elaborada, por colocar os personagens num universo alargado de circunstâncias. Foi com Virgínia que meu foco passou da composição do Narrador para a composição, ainda assim épica, de um personagem complexo e predominantemente dialógico.

\section{Notas}

${ }^{1}$ A VIDA COMO ELA É, encenação dos contos de Nelson Rodrigues, "O Desgraçado", "Uma Senhora Honesta", "Selvageria", "Paixão", "Romântica", "Noiva Para Sempre", "Despeito", "Noiva da Morte", "Doente", "O Justo", "O Aleijado". Recebeu várias indicações para prêmios, conquistando os troféus SATED de Melhor Direção e Melhor Espetáculo. Estréia no Centro Cultural Banco do Brasil, Rio de Janeiro, 1991. Elenco: Maria Esmeralda Forte, Ivo Fernandes, Shimon Nahmias, Nara Keiserman, Francisco de Figueiredo, Denise Izeckson, Eliane Costa, Abelardo Lustosa, substituído por Carlos Pimentel. Cenário e Figurino: Alziro Azevedo; Trilha Sonora: Geraldo Torres; lluminação: Rogério Wiltgen; Máscaras: Malu Rocha e Félix Bressan; Preparação Corporal: Nara Keiserman; Assistente de Direção: Flávio Rocha, substituído por Abelardo Lustosa; Produção Executiva: Márcia Dias; Direção de Produção: Ivo Fernandes e Shimon Nahmias. CÂNDIDO OU O OTIMISMO, novela de Voltaire. O cenógrafo e figurinistaAlziro Azevedo foi indicado, por este trabalho, ao prêmio Shell de Melhor Figurino. Estréia no Centro Cultural Banco do Brasil, 1993. Elenco: Maria Esmeralda Forte, Ivo Fernandes, Shimon Nahmias, Nara Keiserman, Francisco de Figueiredo, Eliane Costa, Maria Adélia. Cenário e Figurino: Alziro Azevedo; Trilha Sonora: Mário Vaz de Melo; lluminação: Rogério Wiltgen; Adereços: Malu Rocha; Preparação Corporal: Nara Keiserman; Assistente de Direção: André Paes Leme; Produção Executiva: Ângela Reis; Direção de Produção: Shimon Nahmias. TRAGÉDIAS CARIOCAS PARA RIR, composta pelos contos "O Morto", de Orígenes Lessa, "Obscenidades Para Uma Dona de Casa", de Ignácio Loyola Brandão, "Noite de Almirante", de Machado de Assis, "Dentro da Noite", de João do Rio e "O Anão", de Rubem Fonseca. Estréia no Teatro Cacilda Becker, Rio de Janeiro, 1996. Elenco: Maria Esmeralda Forte, Shimon Nahmias, Nara Keiserman, Francisco de Figueiredo, Daisy Pozzato e Maurício Grecco, substituído por Sérgio Xavier na segunda temporada. Diretor Colaborador: Renato Icarahy; Cenário: Lídia Kosovski; Figurino e 
Adereços: Samuel Abrantes; Direção Musical: Mauro Perelman; Iluminação: Rogério Wiltgen; Máscaras: Luciana Maia Produção: Assistente de Direção: José Eduardo dos Santos; Produção: Sarau Promoções Culturais Ltda. CORREIO SENTIMENTAL DE NELSON RODRIGUES, cartas publicadas na coluna de correio sentimental que Nelson Rodrigues manteve no jornal Diário da Noite, de abril a dezembro de 1949, sob o pseudônimo de Myrna. Estréia no Teatro Gláucio Gill, Rio de Janeiro, 1999. Elenco: Maria Esmeralda Forte, Nara Keiserman, Francisco de Figueiredo, Ludmila Breitman e Alexandre Bordalo. Cenário: Carlos Alberto Nunes; Figurino: Francisco de Figueiredo; Direção Musical: Demetrio Nicolau; Iluminação: Luis Carlos Nem; Adereços: Carlos Alberto Nunes, Francisco de Figueiredo e Fernando Sant'Anna. Maquiagem: Francisco de Figueiredo; Preparação Corporal: Nara Keiserman; Pesquisa Bibliográfica: Bárbara Carolino; Assistente de Direção: Alex Machado; Produção Executiva: Ângela Blazo; Direção de Produção: Francisco de Figueiredo. A PROSA DO NELSON é composto de crônicas autobiográficas: crônicas I e II,; "Um Menino de Paixões de Ópera" e "Lili Ardeu Como Uma Estrela"; crônicas de futebol: "Duplamente Poeta", "O Deus das Batalhas", "Meu Personagem do Ano", "O Nosso Obdulinho", "O Escrete dos Loucos"; "O Quadrúpede de 28 Patas", "A Realeza de Pelé", "O Pelé Branco", "O Divino Delinqüente", "Descoberta de Garrincha", "Garrincha não Pensa", "O Eichmann do Apito", "Os que Negam Garrincha", "Um Gesto de Amor", "O Grande Dia de Otacílio e Odete"; "Garrincha no Deserto"; e ainda reportagens policiais: "Sofro Só por sua Culpa", "Um Tiro Ecoou Entre os Rumores da Festa e a Jovem Tombou Morta", "A Paixão Religiosa de Maria Amélia”. Estréia no Teatro do Planetário, Rio de Janeiro, 2000. Crônicas Autobiográficas - Direção: Luiz Arthur Nunes; Elenco: Maria Esmeralda Forte, Nara Keiserman, Francisco de Figueiredo, Ludmila Breitman, Alexandre Bordalo, João Paulo Pantoja e Alex Machado; Reportagens Policiais - Direção: Nara Keiserman; Elenco: Henrique Pinho, Natasha Corbelino, Renata Porto, Saulo Rodrigues, Vivian Duarte; Crônicas de Futebol - Direção: Demetrio Nicolau; Elenco: Isabel Peroni, Luciana Ferreira, Maria Luiza Cavalcanti, Mohamed Harfouch, Pedro Rocha, Tatiana Nogueira, Thales Coutinho e Thiago Magalhães. Músicas e Direção Musical: Demetrio Nicolau; Arranjos Vocais e Regência: Sérgio Sansão; Coral: Quebra-Vozes; Figurino: Francisco de Figueiredo; Iluminação: Luca Pergon; Assistente de Direção (autobiográficas): Alex Machado; Produção Executiva: Aduni Benton. UM MENINO DE PAIXÕES DE ÓPERA, frases e crônicas autobiográficas de Nelson Rodrigues: as já mencionadas I, II, "Um Menino de Paixões de Ópera" e "Lili Ardeu Como Uma Estrela", e ainda as crônicas V, X e X2, "O Fascínio por Uma Grande Dor", "A Grande Dor Não se Assoa"; "Pessoas, Mesas e Cadeiras Boiavam no Caos", "O Autor Sem Apoteose". Estréia no Teatro Villa-Lobos, Sala Arnaldo Niskier, Rio de Janeiro, 2000. Elenco: Maria Esmeralda Forte, Nara Keiserman, Francisco de Figueiredo, Ludmila Breitman, 
Alexandre Bordalo e João Paulo Pantoja; Cenário: Carlos Alberto Nunes; Figurino: Francisco de Figueiredo; Direção Musical: Demetrio Nicolau; Iluminador: Luis Carlos Nem; Preparação Corporal: Natasha Corbelino; Assistente de Direção: Alex Machado; Diretor de Produção: Francisco de Figueiredo. A VIDA COMO ELA É, segunda montagem. Estréia no Teatro Carlos Gomes, Rio de Janeiro, 2002. Elenco: Maria Esmeralda Forte, Nara Keiserman (substituída por Dayse Pozzato na segunda temporada), Francisco de Figueiredo, Ivo Fernandes, Eliane Costa, Isaac Bernat, Isabela Lomez, Thiago Magalhães. Cenário e Figurino: Alziro Azevedo, reproduzidos por Carlos Alberto Nunes e Francisco de Figueiredo; Trilha Sonora: Geraldo Torres; Iluminação: Rogério Wiltgen; Máscaras: Fernando Sant'Anna; Adereços: Carlos Alberto Nunes; Maquiagem: Francisco de Figueiredo; Assistente de direção: Alexandre Bordalo; Produção Executiva: Marília Milanez e Analu Tannuri; Direção de Produção: Ivo Fernandes.

2 Especificamente, na Pesquisa Institucional "O Ator Rapsodo: Pesquisa de Procedimentos para Uma Linguagem Gestual", na UNIRIO e no grupo teatral que dirijo, denominado AtoresRapsodos.

${ }^{3}$ Este procedimento é amplamente utilizado na peça O Narrador, com contos de diferentes autores, que dirigi com os AtoresRapsodos, em 2005.

${ }^{4} \mathrm{~A}$ base dos procedimentos gestuais na construção da cena rapsódica do NCT é dada pelo que denominamos de Seqüências de Manipulação, que se organizam em etapas determinadas por modificações no fator peso do corpo do manipulado. As etapas são: Morto, Macaco, Bêbado, Impulso, Bonecos Chineses e Fotograma. Fazemos uma breve explicitação daquelas que são mencionadas, no corpo deste artigo.

\section{Bibliografia}

BRECHT, Bertolt. Teatro dialético - ensaios. Tradução: Luiz Carlos Maciel e outros. Rio de Janeiro: Civilização Brasileira, 1967. Estudos sobre teatro. Tradução: Fiama Pais Brandão. Rio de Janeiro: Nova Fronteira,1978.

KOUDELA, Ingrid. Brecht: um jogo de aprendizagem. São Paulo: Perspectiva, 1991.

LABAN, Rudolf. Domínio do movimento. Tradução: Anna Maria Barros de Vecchi e Sílvia Mourão Netto). São Paulo: Summus, 1978.

NUNES, Luiz Arthur. "Do livro para o palco: formas de interação entre o épico literário e o teatral". Percevejo. Rio de Janeiro: UNIRIO, DTT/PPGT, Ano 8, N.9, 2000, pp 39-51. "O Ator Rapsodo". Rio de Janeiro, 1994. UFRJ, Tese apresentada no Concurso para Professor Titular. 
ROSENFELD, Anatol. O teatro épico. São Paulo: Perspectiva, 1985.

STANISLAVSKI, Constantin. A criação do papel. Tradução: Pontes de Paula Lima. Rio deJaneiro: Civilização Brasileira, 1972. 